\title{
Pelestarian Wayang “Krucil” dan Kekuatan Politik
}

\author{
Dian Suluh Kusuma Dewi ${ }^{1}$, Yusuf Adam Hilman ${ }^{2}$ \\ 'FISIP, Universitas Muhammadiyah, Ponorogo, 63471, suluh.dian@gmail.com \\ 2FISIP, Universitas Muhammadiyah, Ponorogo, 63471, adamhilman@umpo.ac.id
}

Diterima: 16 Agustus 2018

Direview: 17 Desember 2018

Diterbitkan: 31 Desember2018

Hak Cipta (C) 2018 oleh Penulis (dkk)danJurnal Sosial Humaniora (JSH)

*This work is licensed under the Creative

Commons Attribution InternationalLicense (CC

BY 4.0).

http://creativecommons.org/licenses/by/4.0/ Open Access

\begin{abstract}
Subject Area : Social and Politics (Sosial dan Politik)
Abstract

Purpose of the article is to analyze the preservation of puppets "Krucil" and the politic of powers happens in Tempuran village, Sawoo Sub-District, Ponorogo Regency. The method of the article is qualitative descriptive research and it uses in-depth interview for collecting the data. The finding of the study show that; the preservation of the puppets "Krucil" held by the government of Tempuran village annually is by having performance in "Bersih Desa"(annually societies' activity for thanking to God after they get crop) activity. The performance of puppets "Krucil" in "Bersih Desa" activity to entertain the society have been doing since the village founded. The series of events of preservation of puppets "Krucil" are "Ruwatan" ritual conducted by every (head of hamlet), "Brokohan" and recitation of holy Qur'an. While, politic of powers was conducted by including "Bersih Desa" activity and performance of puppet "Krucil" to the village regulations. It was conducted by the head of village in Tempuran District based on the strong of society's myth. The societies believe that there will be crop failure and prolonged disaster if "Bersih Desa" activity don't performance puppets "Krucil”.
\end{abstract}

Keywords: puppets “krucil”, preservation, politic of powers

\section{Pendahuluan/Latar Belakang}

Wayang merupakan budaya Jawa, berasal dari bahasa jawa, yakni "bayang” yang bermakna (bayangbayang), dengan dasar "yang" dan di beri imbuhan "wa", sehingga menjadi "wayang", kata tersebut memiliki persamaan frasa, dengan beberapa penyebutan seperti: "layang, dhoyong, puyeng, reyong, yang memiliki makna bergerak secara terus menerus, tidak tetap, samar serta sayup. Frasa wayang atau hamayang pada zaman dahulu memiliki arti sebuah pertunjukan bayangan (Sulaksono, 2013).

Kesenian wayang merupakan sebuah kesenian yang menceritakan kepahlawan dari tokoh - tokoh baik yang berusaha menumpas tokoh - tokoh yang memiliki karakter jahat. Realitas memberikan gambaran bahwa seni Wayang telah melewati masa demi masa dengan berbagai pristiwa sejarah, dari generasi ke generasi, yang kemudian melekat pada kehidupan masyarakat etnis Jawa. Perjalanan waktu menjawab pertanyaan terkait eksistensi wayang di Indonesia, walaupun sudah mengalami perjalanan panjang, peminat kesenian wayang masih cukup tinggi, selain sebuah kesenian pertunjukan, wayang juga mengandung nilai - nilai luhur, sehingga wayang telah mendapat tempat di hati masyarakat. sebagai sebuah mahakarya tradisional, wayang dianggap sebagai karya sastra yang dikualifikasikan sebaga budaya adhiluhung (Nurgiyantoro, 2011).

Kajian - kajian ilmiah seputar wayang telah banyak dilakukan oleh para peneliti, diantaranya dilakukan oleh Benedict R. O’G. Anderson beliau menghasilkan karya yang berjudul "Mythology and 
The Tolerance of The Javanese" pada tahun 2009, dia melihat seni pertunjukan wayang dalam perspektif sosiologi, selain itu ada juga peneliti lokal yang melakukan kajian wayang pada tahun 1999, yakni Soedarsono, beliau melihat seni pertunjukan wayang dalam berbagai perspektif kajian, diantaranya: perspektif antropologi, konsep tersebut ditulis oleh Victoria M. Clara van Groenendael dengan judul penelitian "Dalang di Balik Layar", selain itu beliau juga mengkaji wayang dalam perspektif komunikasi, itu bisa dilihat dari hasil disertasi yang berjudul "Peranan dalang dalam menyampaikan pesan pembangunan" (Nurrochsyam, 2013).

Masyarakat di Indonesia lebih mengenal wayang, sebagai salah satu keseniaan yang identik dengan suku Jawa, wayang sendiri memiliki berbagai jenis, seperti: wayang kulit, wayang beber, wayang gedog, wayang golek, wayang kulit purwa, dan wayang krucil.

Pada tahun 1986 James T. Siegel membuat sebuah buku, yang berjudul "Solo in The New Order", beliau mengamati tentang model wayang yang ada di kota Surakarta atau solo, kajian ini berfokus kepada, tatanan sosial, budaya, serta politik masyarkaat Jawa, secara dinamik. Pada tahun 1987 terdapat kajian tentang wayang oleh Ward Keeler, beliau mengamati di dunia perwayangan khususnya wayang kulit yang berkembang di wilayah Jogyakarta dan Surakarta, ia ingin melihat sejauh mana interpratasi bentuk kegiatan pagelaran wayang purwa pada khususnya di desa desa yang ada di wilayah Jawa, kemudian menghasilkan sebuah buku yang berjudul: "Javanese Shadow Plays, Javanese Selves". Peneliti asing bernama Clara Van Groenendael juga melakukan kajian terhadap wayang kulit di wilayah Surakarta, dengan menggunakan perspektif antropologis, peneliti tersebut menguak peran dalang sebagai aktivitas pertunjukan kesenian, dan bagaimana relevansinya dengan kehidupan keseharaian dalang di masyarkaat, aktivitas penelitian dilakukan pada tahun 1987, selain Jawa Tengah dan Jogyakarta, kesenian wayang juga terdapat di Provinsi Jawa Timur, beberapa kajian pun telah dilakukan, Soenarto Timoer melakukan kajian terkait aturan tata pagelaran wayang yang terdapat di wilayah Jawa Timur khususnya yang terkait dengan pakemnya, selain itu Umar Kayam pada tahun 2001 membuat buku yang berjudul, "Kelir tanpa Batas", beliau mengkaji model wayang Jawa Timur-an, khususnya wayang Malangan. Suyanto pada tahun 2002 melakukan kajian secara makro, terkait ciri - ciri dinamik pagelaran wayang yang ada di wilayah Malang Raya, atau yang lebih akrab dengan sebutan gaya Jawa Timuran (Christianto, W. 2012).

Indonesia memiliki aneka ragam jenis wayang, di dalam Buku "Baoesastra Djawa Himpunan W.J.S Poerwadarminta", disebutkan jenis - jenis wayang sebagai berikut: 1) Wayang Beber, kain putih yang digambari karakter wayang dan dipertunjukan dengan cara di gelar sambil diceritakan lakonnya oleh sang dalang. 2) Wayang Gedog, wayang yang menceritakan lakon panji. 3) Wayang Golek atau wayang Thengul, wayang yang berupa golekan atau boneka, 4) Wayang Klitik atau Wayang Krucil, wayang yang dibuat dari kayu dibentuk seperti wayang kulit, menceritakan lakon damarwulan. 5) Wayang Kulit, wayang yang dibuat dari kulit sapi atau kerbau menceritakan lakon pada jaman purwo (dulu), misalnya para pandawa, 6). Wayang Madya, wayang kulit yang menceritakan lakon antara jaman purwo dengan cerita baru, 7) Wayang Purwo, adalah wayang kulit, 8) Wayang Potehi, wayang thithi atau wayang cina, yaitu wayang golek yang menceritakan lakon cina, 9) Wayang Wong, yaitu wayang yang dimainkan oleh (wong) orang (Yudiarti, 2010). 
Wayang Krucil Sering dianggap sama dengan jenis wayang klitik, asumsi tersebut dikarenakan wayang jenis ini, terbuat dari kayu pipih. Ada beberapa perbedaan yang kentara, dimana induk cerita yang diambil untuk tokoh - tokohnya, diambil dari cerita Panji, bukan dari cerita Ramayana atau Mahabarata, seperti jenis wayang konvensional yang di kenal masyarakat luas (Tanudjaja, 2004).

Kesenian wayang "krucil" memang tidak sepopuler wayang kulit yang ada di Pulau Jawa, walaupun demikian, Seni tradisi ini pernah mengalami masa kejayaan pada era 60-an. Pagelaran Wayang Krucil dalam kehidupan masyarakat, tidak hanya sebagai hiburan, akan tetapi di dalam pertunjukannya selalu di sertai dengan pesan - pesan budaya, yang luhur seperti, nilai-nilai sejarah, moral dan etika.

Keberadaan wayang Krucil di wilayah Kabupaten Ponorogo, tersebar di wilayah kecamatan Sawoo, tepatnya di desa Tempuran. Hal itu terlihat ketika diadakan acara bersih desa, di barengkan setelah kegiatan malam tirakatan, dengan dalang $\mathrm{Ki}$ Sardi (68 tahun) dari Kabupaten Trenggalek.

Drama wayang Purwa dapat dikelompokkan ke dalam beberapa cerita, di antaranya: Arjunasasrabahu di ambil dari Serat Lokapala, Siklus Rama di ambil dari cerita Ramayana, serta siklus Pandawa yang diambil dari cerita Mahabharata, selain beberapa cerita di atas, biasanya wayang diambil dari cerita Menak, cerita Panji, cerita binatang, atau bahkan dari cerita lainnya, misalnya: cerita keagamaan, seperti: wayang sadat, wayang wahyu, atau juga biasanya diambil dari kisah perjuangan bangsa Indonesia dalam mencapai kemerdekaan, seperti: wayang perjuangan, wayang Pancasila (Suwardi, 2012).

Kebudayaan wayang pada masyarakat Jawa, memiliki model serta jenis, yang mengisahkan berbagai cerita yang di sadur dari beberapa dokumen serat pada masa kerajaan, seperti penuturan diatas memberikan gambaran kepada kita tentang pertunjukan wayang yang menampilkan, pesan pesan dari internalisasi nilai, yang disematkan dalam setiap pertunjukan.

Pertunjukan wayang tidak hanya aktivitas kesenian, namun banyak orang yang percaya bahwa terdapat pesan - pesan moral, dan falsafah hidup khususnya suku Jawa, jika kita lihat dalam setiap pertunjukan wayang, terdapat tokoh - tokoh atau lakon, yang menjadi refleksi dari sikap, watak, dan karakter masyarakat yang ada di dunia, ada peran antagonis ataupun protagonis, ada kejahatan, kebathilan, keburukan, cinta, kasih sayang, dengki, serakah atau tamak, dan masih banyak lainnya (Tjintariani, 2014).

Romo Frans Magnis-Suseno berpendapat bahwa terdapat 4 (empat) lingkaran atau circle dalam pandangan dunia Jawa. Pertama, terkait dengan sikap atas keberadaan dunia luar, yang dialami manusia beretnis Jawa sebagai sebuah kesadaran antara manusia, alam, serta dunia kodrati. Kedua, bagaimana penghayatan kekuasaan politik sebagai sebuah hal yang menjadi kepanjangan kekuasaan atau kekuatan adikodrati. Ketiga, pengalaman empiris spiritual masyarakat Jawa terkait pemahaman tentang keberadaannya di alam semesta. Keempat, kesatuan dari ketiga lingkaran sebagai sebuah kesatuan masyarakat Jawa (Chalik, 2015).

Orang Jawa menurut pandangan dunia, merupakan realitas yang tidak bisa dipisahkan, secara sederhana di contohkan, bagaimana masyarakat Jawa dalam kehidupan sehari - hari tidak bisa melepaskan konsep ketuhanan, pesta panen, dengan bencana sehingga dapat diartikan secara ringkas, jika pemerintahan dijalankan secara otoriter akan berakibat 
pada kekuasaan yang absolute, maka raja atau pemimpin yang cenderung berbuat lalim, atas dasar legitimasi ketuhanan. Hal tersebut akhirnya menyebabkan kegagalan panen dan menimbulkan wabah penyakit.

Orang Jawa meyakini jika dunia dan ruang tempatnya beraktivitas, sebagai sebuah kesatuan yang tidak bisa terpisahkan dan itu mereka sadari, keberadaan etnis Jawa akhirnya memahami kehidupannya sebagai sebuah "res cogitans," sehingga manusia Jawa memiliki kemampuan untuk merefleksikan kehidupan, hal ini terkait dengan eksistensi masyarakat yang menyatu dengan alam.

Konsep kepemimpinan Jawa terlihat dari keterikatan Tuhan, alam dan manusia, perjalanan sejarah telah memberikan gambaran, bagaimana model kepemimpinan Soekarno sebagai seorang beretnis Jawa, selain kehidupan keseharian Bung Karno, latar belakang sosial masyarakat Jawa terhadap beberapa ciri khas, misalnya terkait budaya sinkretis, model kehidupan yang berbau mistik, selain itu pengaruh hindu juga terlihat, dalam beberapa literatur menjelaskan bagaimana Bung Karno sangat menyukai cerita pewayangan, terutama jika berkenaan dengan tokoh pewayangan bernama "Bima", hal tersebut sangat memengaruhi cara berpikir dan sikap Soekarno sebagai orang Jawa, dalam perkembanganya Soekarno kemudian berkenalan dengan tokoh - tokoh nasional dari blok kanan ataupun kiri, serta dari kalangan agamis, sehingga kemudian Sukarno dewasa memiliki karakter kepemimpinan dengan beberapa model, yakni; Jawa tradisional, nasionalisme, Islam, dan Marxisme (Chalik, 2015).

Kesenian wayang yang dipertunjukkan di Desa Tempuran Kecamatan Sawoo Kabupaten Ponorogo, merupakan salah satu ekternalisasi dari Nilai-nilai mitos yang dipercayai oleh masyarakat secara turun - temurun. Mitos kesakralan pagelaran wayang krucil dan nilai spiritual pada malam tirakatan, mengambarkan jika masyarakat Jawa yang ada di desa tersebut, memiliki kedekatan dengan Tuhan dalam menjalankan aktivitasnya, seperti yang dijelaskan oleh Romo Magnis, perilaku itu tercermin ketika mereka merasa takut akan gagal panen, atau musibah yang akan menimpa mereka, seperti bencana alam longsor, kebakaran hutan, sehingga pemerintah kemudian menangkap hal tersebut ke dalam sebuah kebijakan, dengan cara melakukan pelestarian wayang krucil dalam kegiatan bersih desa setiap tahunnya, kemudian pelestarian tersebut tertulis dalam peraturan Desa Tempuran Kecamatan Sawoo Kabupaten Ponorogo. Pelestarian wayang krucil yang kemudian tertulis secara jelas di peraturan Desa Tempuran, tentu saja menjadi hal yang unik dan layak untuk dikaji lebih dalam.

Kepercayaan masyarakat Jawa terhadap nilai dan tatanan kehidupan, tereduksi dengan kehidupan sehari - hari, keyakinan tersebut kemudian, terlembagakan dalam komunitas masyarakat yang ada, dengan nilai - nilai yang di junjung sebagai sebuah keyakinan.

Koentjaraningrat mengutarakan tentang nilai budaya yang merupakan konsep hidup yang muncul, serta tumbuh di pemikiran manusia, kemudian di yakini karena keangungan nilai tersebut, keberadaan sistem nilai dalam sebuah komunitas masyarakat, akan dijadikan sebagai referensi dalam bertindak, sehingga budaya tersebut akan mempengaruhi masyarkaat (Sartini, 2009).

Poin penting dari persoalan budaya dalam kehidupan masyarakat, menurut Kluckohn, terdapat lima poin, yakni: (1) hakikat hidup, (2) hakikat karya manusia, (3) hakikat kedudukan manusia, (4) hakikat hubungan manusia dengan alam sekitar dan (5) 
hakikat dari hubungan manusia dengan manusia sesamanya (Sartini, 2009).

Masyarakat Jawa dengan kompleksitas persoalan yang terjadi dalam kehidupan sehari - hari, mencoba untuk mempertahankan nilai - nilai sebagai sebuah keyakinannya, komunitas masyarakat yang ada di Kecamatan Sawoo Kabupaten Ponorogo, melalui kepala desa mencoba mempertahankan dan membentuk pemahaman masyarakat terkait nilai nilai yang dilandasi melalui berbagai budaya dan tradisi.

Pelembagaan nilai - nilai pada masyarakat yang dilakukan oleh kepala desa, merupakan bentuk atau proses internalisasi nilai pada komunitas masyarakat di kecamatan Sawoo, sehingga menguatkan keyakinan masyarakat terhadap nilai nilai tersebut, di sisi lain kegiatan tersebut juga memberikan gambaran terkait upaya yang dilakukan dalam rangka melestarikan wayang krucil.

Upaya pelestarian kesenian wayang krucil, yang dilakukan pemerintah desa, didominasi oleh peranan kepala desa, hal ini merupakan bentuk legitimasi dari kekuasaan yang dimilikinya, melalui kesenian ini kepala desa melakukan praktik hegemoni, dengan cara memasukan praktik - praktik mempengaruhi masyarakat, guna memperkuat pengaruhnya sebagai kepala desa.

Praktik hegemoni yang sering dijelaskan oleh Antonio Gramsci, sebuah kelas sosial satu dengan lainnya, biasanya dilakukan dengan cara dominasi dan paksaan (coercion) serta melalui saluran norma yang ada dalam sebuah masyarakat, sehingga suatu kelas kemudian memahami itu sebagai bentuk ketertundukan, John Storey, menegaskan jika proses hegemoni, ditandai dengan sebuah kondisi dimana kelas yang lebih mendominasi tidak hanya memerintah atau dilakukan dnegan paksaan, tetapi juga dilakukan dengan kepeminpinan moral, yang dimaksud adalah bentuk pelembagaan nilai - nilai yang diakui oleh masyarakat yang terhegemoni. Praktik hegemoni kemudian memunculkan penerimaan dan dukungan yang kuat terhadap ide ide, makna serta tujuan budaya secara lebih besar dan kuat, melalui struktur sosial yang ada (Boer, 2012).

Pengaruh dalam hal ini adalah cara untuk mengontrol masyarakat atau kelompok lain melalui kekuasaan, hal tersebut dapat kita lihat dalam model hirarki masyarakat yang ada pada wilayah pedesaan, hal ini terkait dengan relasi kekuasaan (power) yang dipadukan dengan konsep kewenangan (Authority) dalam konteks sistem pemerintahan desa.

Kekuasaan yang melekat pada individu ataupun secara kelompok, untuk mempengaruhi individu ataupun kelompok lain, secara nyata secara logika hal tersebut terjadi pada masyarakat modern, khususnya terkait dengan kekuasaan dan juga kedaulatan dan konsep hukum. konsep ini, ada dan diyakini dalam struktur masyarakat, serta diakui secara hukum melalui mekanisme consensus (Mudhoffir, 2013).

Tujuan utama dalam praktik tersebut yakni mempengaruhi khalayak, sehingga membentuk persepsi yang akan membuahkan image atau pencitraan yang baik di kalangan masyarakat desa, upaya tersebut merupakan tindakan rasional yang dapat dilakukan oleh kepala desa, hal tersebut bisa dilakukan melalui saluran - saluran komunikasi seperti media baik cetak atau daring, yang bersifat informal ataupun interpersonal.

Kepala desa bisa memperoleh persepsi yang baik, melalui mekanisme atau proses komunikasi, menggunakan media massa seperti: Majalah, televisi, radio, media sosial, ataupun bisa juga melalui non media massa, seperti leaflet, spanduk, dan juga baliho, 
saluran komunikasi interpersonal, kelompok, organisasi dan jaringan komunikasi (Nugraheni Arumsari, 2017)

Wayang krucil menjadi alat hegemoni, dimana tradisi pementasan wayang tersebut, banyak menampilkan cerita - cerita, tentang: moral, etika, dan juga sejarah, di sinilah cerita - cerita tersebut di konstruksi melalui pertunjukan wayang.

Karya sastra merupakan replika kehidupan masyarakat yang disarikan dengan imajinasi pengarang kemudian dituangkan dalam peristiwa fiksi lalu disajikan pada pembaca (masyarakat). Sajian fiksi tersebut kemudian dinikmati oleh pembaca dan bahkan pesan yang dikomunikasikan pengarang lewat satra tersebut diikuti dan menjadi sebuah acuan dalam pola pikir pembaca. Semakin tinggi kadar kontekstualitas sebuah paparan fiksi maka semakin memungkinkan memiliki kekuatan hegemonik. Kekuatan hegemoni sastra tersebar pada masyarakat pendukungya dan selalu menyesuaikan dengan perkembangan zaman dari kehidupan masarakat tradisional di masa lalu hingga masyarakat modern seperti sekarang ini (Sulaiman, 2017).

Tujuan dari penelitian ini adalah menganalisis model pelestarian wayang krucil dan bentuk politik kekuasaan yang terjadi di Desa Tempuran Kecamatan Sawoo Kabupaten Ponorogo.

Pertunjukan wayang Krucil yang sudah menjadi agenda wajib Desa Tempuran, merupakan proses penanaman nilai - nilai masyarakat Jawa, terkait kepercayaan masyarakat atas segala sesuatu kehidupan yang tidak bisa dilepaskan dari kuasa Tuhan, kemudian pagelaran tersebut memperlihatkan bagian - bagian cerita yang disajikan dengan kontekstualisasi kehidupan masyarakat sebagai makhluk religius. Penyelenggaraan pagelaran wayang tersebut dimanfaatkan oleh Kepala Desa untuk melakukan hegemoni secara halus melalui dominasi budaya, yang menjadi persoalan bahwa pertunjukan wayang lebih dominan untuk kepentingan sekelompok orang saja, bukan bertujuan untuk melestarikan budaya wayang sendiri.

Fenomena tersebut memperlihatkan bahwa ada kepentingan dalam pertunjukan tersebut, Kepala Desa mencoba mengambil keuntungan untuk mempengaruhi khalayak dalam hal ini masyarakat desa melalui pertunjukan wayang, yaitu bagaimanakah hal tersebut bisa mempengaruhi masyarakat, terkait pertunjukan wayang yang dilaksanakan.

\section{Metode Penelitian}

Penelitian yang dilakukan ini berjenis kualitatif, deskriptif, dimana peneliti ingin memperoleh gambaran yang jelas secara deskriptif. Lokasi penelitian bertempat di Desa Tempuran, Sawoo, Ponorogo, alasannya karena pagelaran wayang krucil menjadi kegiatan rutin setiap tahun di Desa Tempuran Kecamatan Sawoo Kabupaten Ponorogo yang kemudian dikemas dalam kegiatan bersih desa. Hal tersebut merupakan suatu pelestarian yang sudah dilakukan sejak dahulu.

Burhan Bungin menuturkan jika arah dari penelitian yakni produk berpikir terkait fokus kajian yang akan diteliti, sehingga akan memperoleh jawaban sementara, model inilah yang kemudian disebut sebagai, cara berpikir induktif (Rahman, 2012)

Informan dalam penelitian ini adalah Kepala Desa Tempuran, tokoh masyarakat, serta Dalang Wayang Krucil dan beberapa masyarakat yang dianggap memahami keterkaitan pagelaran wayang krucil dan mitos gagal panen. Jumlah dari Informan dalam penelitian ini sebanyak 5 (lima) orang dengan 
rincian sebagai berikut: 1). Kepala Desa Tempuran sebanyak 1 (satu) orang, 2). Tokoh masyarakat sebanyak 1 (satu) orang, 3). Dalang Wayang Krucil sebanyak 1 (satu) orang, 4). Masyarakat Desa Tempuran sebanyak 2 (dua) orang. Penentuan informan dengan menggunakan proposive sampling, dengan penentuan informan dengan pengetahuan yang dimiliki terhadap obyek kajian, sehingga dapat memberikan informasi berupa data wawancara yang dibutuhkan.

Kepala desa dijadikan sebagai informan karena dianggap sebagai salah satu aktor yang terlibat dalam pembuatan dalam hal ini yang mengagas pertunjukan wayang Krucil sebagai agenda wajib desa. Tokoh masyarakat dijadikan sebagai informan karena dianggap mengetahui tentang seluk-beluk munculnya kesenian ini yang dijadikan sebagai ritual bersih desa di Desa tempuran Kecamatan Sawoo, Kabupaten Ponorogo. Dalang Wayang Krucil dipilih sebagai informan, dikarenakan salah satu tokoh kunci dalam pagelaran wayang tersebut, di sinilah dalam memainkan peranan untuk menyampaikan pesan dalam pertunjukan tersebut. Masyarakat yang dijadikan sebagai informan adalah warga masyarakat yang bertempat tinggal di Desa Tempuran Kecamatan Sawoo Kabupaten Ponorogo.

Keempat Informan tersebut, kemudian diwawancarai secara mendalam, terkait Pagelaran Wayang Krucil. Hal ini terkait alasan diselenggarakannya pertunjukan tersebut, pesan apa yang disampaikan, hingga maksud dimasukkannya pagelaran Wayang Krucil sebagai agenda wajib desa.

Purposive sampling lebih menekankan pada tindakan pemilihan informan atas dasar sebagai sumber informasi, dan juga keluasan data yang dapat dia berikan, selain itu model ini menjelaskan bahwasanya informan memiliki keterkaitan dengan masalah penelitian atau obyek yang akan diteliti, akan tetapi perlu diingat perlu dilakukan pengembangan data, sesuai dengan kebutuhan data dalam sebuah penelitian (H.B. Sutopo, 2006).

Obyek yang diteliti dalam penelitian ini adalah Pagelaran Wayang Krucil sebagai bagian dari tradisi lokal yang memiliki pesan - pesan moral terhadap masyarakat, serta apa yang menjadi alasan mendasar memasukan pagelaran tersebut sebagai agenda wajib "Bersih Desa" di Desa Tempuran Kecamatan Sawoo Kecamatan Ponorogo.

Kualitatif merupakan metode penelitian yang sesuai untuk menganalisis sebuah obyek, metode ini bisa dipasangkan dengan model pendekatan studi kasus, karena diperlukan obyek penelitian yang spesifik, Salim menyatakan bahwa diperlukan kekhususan dan juga keumuman sebuah obyek kajian. Beliau membuat beberapa hal yang terkait dengan keunikan sebuah obyek penelitain, diantaranya: (1) hakikat dari kasus tersebut, (2) latar belakang historis (3) setting fisik, (4) konteks kasus, khusunya ekonomi, politik, hukum dan estetika, (5) kasus-kasus lain disekitar kasus yang dipelajari, (6) informan atau pemberi informasi tentang keberadaan kasus tersebut, model pendekatan ini biasanya mengharuskan peneliti untuk mengumpulkan semua sumber data yang terkait dengan poin - poin tersebut (PRAJAYANTI, 2012).

Data yang digunakan dalam penelitian ini adalah data hasil wawancara dari informan yang telah disiapkan untuk mendapatkan data - data penting yang dibutuhkan. Wawancara mendalam adalah salah satu teknik dalam pengumpulan data, dalam praktiknya wawancara mendalam tidak dilakukan secara tertruktur dan formal, keluesan, dan keakraban peneliti dengan infroman di butuhkan agar suasana tidak menjadi kaku. Pelengkap wawancara mendalam, diperlukan teknik observasi yang mendalam juga, 
sehingga data yang diperoleh memiliki tingkat kedalaman yang baik, sesuai dengan kebutuhan data penelitian.

Metode kualitatif biasanya menggunakan Triangulasi untuk mengukur kebenaran sebuah hasil penelitian, bisa dengan mengukur data dengan data dari sumber lainnya, hal ini akan memberikan keyakinan kepada peneliti, dalam proses penyusunan kesimpulan (Bachr, 2010).

Triangulasi terdiri dari beberapa jenis, diantaranya: triangulasi sumber dipakai untuk melakukan pengujian terkait derajat ketepatan dan kelengkapan data, yang diperoleh. Triangulasi personal (informan), dipakai terkait untuk melakukan uji dari tingkat keakuratan atau kesahihan data. Triangulasi teori, dipakai untuk pengujian terhadap derajat kepercayaan temuan atau hasil penelitian. d). Triangulasi metode digunakan untuk menguji atau mengecek derajat kepercayaan penemuan hasil penelitian (Sunarni, 2018). Penelitian ini menggunakan model Trianggulasi Teori yakni mengkaji derajat kepercayaan temuan data di lapangan atau hasil penelitian dengan teori yang ada, dalam hal ini yakni konsep hegemoni.

Proses penelitian ini dapat dipahami dari gambar 1.

Gambar 1 Prosedur Penelitian

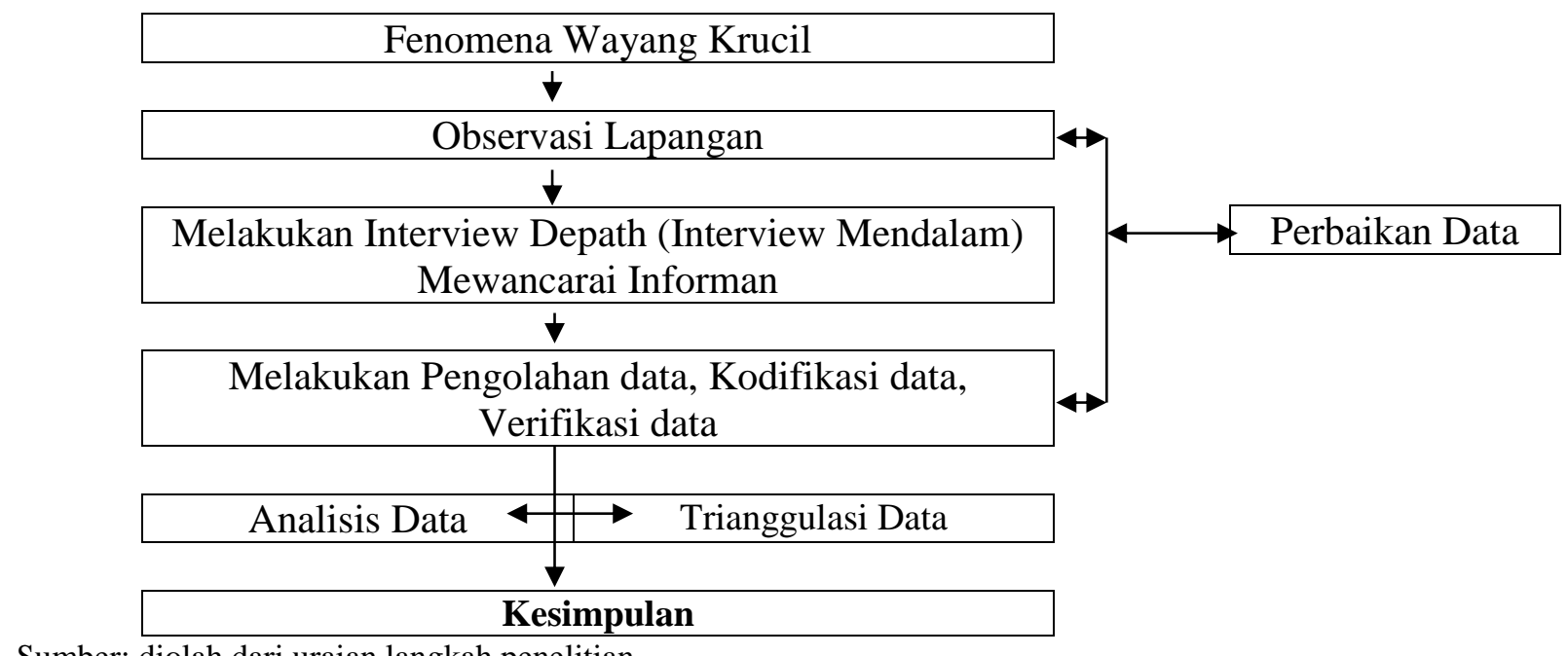

Sumber: diolah dari uraian langkah penelitian

\section{Hasil Penelitian dan Analisis}

\section{Hasil Penelitian}

\section{Pelestarian Wayang Krucil di Desa Tempuran}

\section{Kecamatan Sawoo Kabupaten Ponorogo}

Menurut Bapak Suroso Mantan Kades Tempuran: "Jadi ceritanya, di tempuran itu punya rojo pati mas. Rojo pati itu istilahnya musibah yang akhirnya banyak orang mati. Seperti kelaparan, paceklik gara-gara panen gagal, terus kendat (gantung diri), orang bertengkar sampai saling membunuh. Nah suatu hari, di tahun 1970 berapa saya lupa tepatnya, ada salah satu sesepuh desa yang mendapat wangsit (pesan khusus) supaya desa tempuran ini harus diruwat. Nah terus para sesepuh dusun berkumpul untuk bermusyawarah mengenai ruwatan desa itu. Akhirnya dibuat kesepakatan setiap tahun desa harus diruwat, rangkaian acaranya ya malam tirakatan, ada ritualan di sendang-sendang, sama wayang krucil. Wayang krucil ini sebagai syarat, jadi nggak boleh diganti dengan wayang lainnya"

Menurut Misnianto Kepala Desa Tempuran: "Masyarakat disini kan percaya dengan mitosmitos mas. Mitosnya kalau wayang krucil ini bisa membantu untuk menghindari dari musibah. Jadi ya kami sebagai pemerintah desa merasa perlu 
untuk melestarikan wayang krucil dan memasukan ke perdes. Supaya kegiatan ini terus berkelanjutan sampai anak cucu nanti. Dan warga saya juga merasa tenang, tidak perlu takut akan musibah-musibah yang akan dating. insyaAllah nggak akan ada musibah besar lagi yang melanda masyarakat"

Menurut Wawan warga tempuran:

"Kami percaya kalo di desa ini ada kepercayaan tentang penjaga desa, yang harus di jaga dengan melakukan kegiatan bersih desa, dengan melakukan pertujukan wayang, ini sudah berlangsung lama, namun keberadaan seniman wayang krusil semakin lama, semakin sulit keadaanya.

Desa Tempuran dipercaya memiliki rojo pati (musibah) sehingga pada awal berdirinya desa Tempuran seringkali terjadi kejadiankejadian tragis dan bencana alam. Kepala desa kemudian melakukan pendekatan dan diskusi dengan para sesepuh desa. Para sesepuh kemudian melakukan malam tirakatan yang kemudian mendapatkan wangsit (pesan khusus) agar dilaksanakan malam tirakatan dan ritual ruwatan desa dengan menggunakan wayang krucil. Sebelum ruwatan desa dilaksanakan, para kamituwo di 4 dusun di Desa Tempuran (Dusun Manding, Dusun Poko, Dusun Kudo Sentono, Dusun Sentono) melakukan brokohan (makan bersama dengan menu ingkung) kemudian dilanjutkan ritual nyekar (tabur bunga) di 4 lokasi danyangan (tempat yang dikeramatkan). Setelah selesai ruwatan dan pagelaran wayang krucil, para kamituwo menanam sesaji di 4 danyang. Empat dusun yang ada, setiap dusunnya memiliki danyangan.

Nilai mitos yang diyakini oleh masyarakat Desa Tempuran pada ritual pagelaran wayang krucil sangatlah mengakar hingga kelas terkecil dalam masyarakat. Mereka percaya bahwa dengan melakukan pagelaran wayang krucil setiap tahunnya akan dapat membantu menjauhkan masyarakat dari berbagai macam musibah seperti; pembunuhan, kematian tragis, gagal panen dan bencana lainnya.

Berangkat dari kondisi di atas, maka pada tahun 2010 pemerintah desa Tempuran memasukkan pagelaran wayang krucil pada peraturan desa. Pagelaran wayang krucil di Desa Tempuran dilaksanakan setiap tahun dalam kegiatan bersih desa. Rangkaian kegiatan bersih desa dilaksanakan beberapa acara yaitu pengajian dan pagelaran wayang krucil yang disertai dengan ritual ruwat desa. Ruwat desa dilaksanakan bertujuan untuk menjauhkan desa Tempuran dari musibah dan bencana.

Pada tahun 70-an, desa tempuran mengalami banyak musibah dan bencana. Pembunuhan dilakukan oleh sepasang suami istri, mati dengan cara gantung diri, mengubur hiduphidup bayi yang baru dilahirkan, paceklik, banjir, jembatan putus.

\section{Pertunjukan Wayang Krucil}

Menurut Ki Sardi Dalang Wayang Krucil, Mengatakan bahwa:

"Dalam pertunjukan wayang biasanya saya menampilkan pertunjukan dengan mengisahkan kehidupan masyarakat yang syarat dengan pesan moral, bagaimana manusia harus selalu "nguringuri" atau menasehati supaya menjaga budaya jawa termasuk wayang krucil ini."

Menurut warto sebagai penonton:

"pertujukan yang saya lihat yakni bercerita tentang sebuah alam yang ditinggali oleh manusia, dengan tiga tokoh yang memiliki peran penting, yakni: tokoh utama, tokoh antagonis atau musuh dari peran utama, dari tontonan tersebut saya mendapatkan beberapa pesan, diantaranya: 1).disini saya memperoleh hiburan yang banyak memberikan pesan - pesan sosial. 2). Saya mendapatkan banyak masukan terkait kehidupan saya sebagai individu dan juga kelompok, yang 
harus menyelaraskan kehidupan dengan sesama manusia dan juga kepada sang pencipta."

Menurut Kuntjaraningrat menjelaskan bahwa, kebudayaan adalah keseluruhan sistem gagasan, tindakan dan hasil karya manusia dalam rangka kehidupan masyarakat yang dijadikan milik manusia dengan belajar. Selanjutnya, ia membedakan wujud kebudayaan dibagi menjadi tiga, yaitu: 1). wujud kebudayaan sebagai suatu kompleks ide, gagasan, nilai, norma, dan peraturan. 2), bentu atau wujud kebudayaan merupakan sebuah tindakan berpola oleh manusia dalam masyarakat, dan 3). wujud kebudayaan sebagai benda hasil karya manusia. (Minarto, 2007)

Pertunjukan wayang krucil yang dipentaskan banyak menampilkan pesan - pesan sosial terhadap kehidupan masyarakat, dimana dalam pesan tersebut masyarakat diarahkan untuk menjadi individu yang selaras dengan sang pencipta yang telah memberikan anugerah dan kenikmatan hidup, sedangkan secara berkelompok manusia diharapkan untuk bisa bersosialisasi dan menjaga harmonisasi dengan kehidupan sesama makhluk ciptaan Tuhan, supaya persaudaraan dan juga nilai - nilai gotong royong bisa terus di jaga.

\section{Wayang Krucil: Politik Kekuasaan}

Menurut Nurjaman, Perangkat desa :

"Sebenarnya, desa memasukan riggit krucil ke perdes ini sebagai antisipasi saja mas. Supaya ketika nanti kepala desa nya ganti, itu tidak merubah tradisi, itu saja kok mas. Dan proses masuknya perdes itu juga sudah benar, jadi ya nggak masalah. Hitung-hitung ini juga untuk pelestarian ringgit krucil supaya anak-anak muda tahu"

Menurut Ki Sardi Dalang Wayang Krucil, Mengatakan bahwa:

"Ya kalau saya setuju-setuju saja mas. Karena wayang krucil ini dibilang sudah hampir punah.
Anak-anak muda sekarang nggak tahu dengan wayang krucil. Tanggapan juga sangat jarang. Dalang wayang krucil yang masih ada juga tinggal sedikit. Jadi ya saya senang kalau desa Tempuran ini melestarikan wayang krucil sebagai kekayaan budaya dan tradisi yang hamper punah"

Menurut Misnianto Kepala Desa Tempuran:

"Alhamdulillah masyarakat mendukung mas, lha wong memang prosesnya melalui musyawarah desa kok", "ya itu memang hasil musyawarah pemerintah desa dengan semua sesepuh desa dan tokoh masyarakat. Sebenarnya bukan cuma wayang krucil mas, tapi ada ruwatan dan malam tirakatan. Awalnya, waktu itu ada sesepuh yang dapat wangsit, untuk dilakukan malam tirakatan untuk tolak balak. Malam tirakatan sekaligus pagelaran wayang krucil. Kalau pagelaran wayang krucil disini sudah sejak lama"

Menurut Gunawan Masyarakat Desa Tempuran: "Kami sangat menyukai pertunjukan wayang krucil, selain dalangnya bagus, ceritanya juga sangat penuh dengan pesan moral dan perjalanan sejarah desa, kami juga di ingetkan kembali soal struktursosial dan kebudayaan jawa, sehingga saya menikmati cerita tersebut"

Pelanggengan kekuasaan yang terjadi di Desa Tempuran adalah dengan cara memasukkan nilai-nilai mitos dan kepercayaan pada pagelaran wayang krucil, dimasukkan pada peraturan desa tahun 2010. Pelestarian wayang krucil sejak tahun 2010 merupakan kegiatan yang harus dilakukan oleh desa pada kegiatan bersih desa.

Kepala desa menjadi sosok yang benar benar memiliki kekuasaan sekaligus sentral dari kekuasaan itu sendiri, posisi kepala desa yang strategis akhirnya menjadikan sosok kepala desa sebagai penghubung yang memiliki fasilitas yang diperuntukan untuk suprastruktur yang ada di desa. Sifat kekuasan yang melekat pada kepala desa ada dua (position power dan personal power).

- Position power; dilihat dari kekuasaan yang melekat pada kepala Desa Tempuran, tentu 
saja sebagai kepala desa, Sdr. Misnianto menggunakan kekuasaannya untuk melakukan perubahan kebijakan. Adapun kebijakan pelestarian wayang krucil dimasukkan pada peraturan desa tahun 2014.

- Personal power; Misnianto sebagai kepala desa tentu saja mempunyai kekuasaan personal yang baik dengan masyarakat desa Tempuran. Hal ini dilakukan dengan melakukan komunikasi dan silaturahim yang intens. Komunikasi dan silaturohmi diwujudka dengan menghadiri setiap undangan yang diberikan oleh warga seperti, arisan RT, pengajian, kegiatan karang taruna dan lain sebagainya.

Fenomena wayang krucil yang ada di wilayah tempuran kecamatan sawoo, memberikan gambaran terkait bagaimana masyarakat Jawa memiliki model kepemimpinan, yang bercirikan, sebagai berikut: 1) kharismatik mistik, 2) kharismatik filosofis, dan juga, 3) eufemistik, yang tereduksi melalui kebudayaan wayang dan kepercayaan masyarakat, sehingga nampak jelas, kepala desa, memiliki kecakapan dalam memimpin komunitas masyarakat Jawa di daerah tersebut.

Ritual yang dilakukan adalah bentuk upacara yang berkaitan dengan, kepercayaan masyarakat atau keyakinan yang telah "mendarah daging", hal tersebut kemudian ditandai dengan bentuk penghormatan kepada leluhur atau sesepuh desa, atau terkadang merujuk pada pengalaman spiritual masyarakat tersebut. Kontektualisasi ritual tersebut kemudian diwujudkan melalui bentuk - bentuk komunikasi masyarakat dengan alam transendental, melalui media persembahan atau penyuguhan kepada hyang/sing mbahureksa desa. Pola hubungannya atau komunikasi yang tampak, bersifat khusus atau istimewa, sehingga manusia membuat model keterhubungan. Inti dari ritual: kepercayaan, keyakinan, ataupun agama merupakan sebuah ungkapan ataupun permohonan atas rasa syukur kepada yang dihormati atau yang berkuasa, acaranya pun kemudian diselenggarakan secara khusus, di tempat yang khusus pula, dilengkapi dengan berbagai peralatan ritual, yang bersifat sakral atau memiliki kekuatan (dalam bahasa Jawa dinamakan) “ubarampen sesaji” (Minarto, 2007).

\section{Analisis Data}

Pertunjukan Wayang Krucil di Desa tempuran sudah dilaksanakan pada tahun 70-an, kemudian pada tahun 2010 pemerintahan desa di bawah kepemimpinan Misnianto sebagai kepala desa telah memasukan kegiatan Wayang Krucil sebagai agenda wajib desa pada kegiatan "Bersih Desa", dan dilegalkan dalam Peraturan Desa pada tahun 2010 sebagai produk hukum.

Pagelaran Wayang Krucil pada awalnya merupakan sebuah tradisi yang lahir dari kondisi desa yang banyak mengalami musibah, kemudian para pendiri desa mendapatkan wangsit untuk melakukan pertunjukan seni wayang untuk menolak "bala", Pertunjukan wayang Krucil berisi pesan moral kepada masyarakat, isi pesannya berupa anjuran untuk tidak serakah, tamak, dan juga manusia sebagai bagian dari jagat raya dan harus bisa bersinergi dengan alam, supaya tidak mendapat murka dari Tuhan Yang Maha Esa.

Pelembagaan pelestarian wayang Krucil melalui peraturan desa yang menjadikan pagelaran tersebut menjadi bagian wajib di tiap tahun, kemudian secara sederhana hal tersebut kemudian dimanfaatkan oleh kepala desa untuk melanggengkan kekuasaannya, karena keyakinan masyarakat 
terhadap nilai ritual pertunjukan wayang Krucil maka dalam setiap pertunjukan kepala desa bisa melakukan intervensi pesan - pesan terhadap dalang wayang Krucil yang akan disampaikan kepada khalayak dalam hal ini masyarakat tempuran. Pesan yang disampaikan mengarah pada cerita - cerita wayang yang mengarah pada penguatan figur kepala desa di hadapan warga masyarakat. Model ini disebut hegemoni dengan bentuk dominasi, atau cara menghegemoni melalui praktik kebudayaan yang dikonstruksi secara halus dan sopan. Posisi kepala desa yang strategis menjadikan peranannya sangat vital dalam proses hegemoni tersebut.

Instrumen kebijakan yang tertuang dalam peraturan desa menjadi bukti bahwa kepala desa melakukan hegemoni, untuk menguasi alat - alat komunikasi yang ada di lingkungan masyarakat desa, salah satunya adalah pertunjukan wayang Krucil.

\section{Kesimpulan}

Bentuk pelestarian wayang krucil yang dilakukan oleh pemerintah desa, berwujud pagelaran Wayang Krucil setiap tahunnya, melalui kegiatan bersih desa. Cerita wayang menjelaskan tentang sistem sosial masyarakat dan juga kebudayaan lokal, yang memperkuat keyakinan masyarakat, di dalam cerita wayang tersebut juga dijelaskan tradisi - tradisi orang Jawa, seperti unggah - ungguh (tata karma), hirarki sistem sosial masyarakat, ini semua menjadi kepercayaan masyarakat Desa Tempuran. Nilai-nilai mitos yang dipercaya oleh masyarakat Desa Tempuran diantaranya bahwa wayang Krucil adalah salah satu bentuk ritual penolak bala' atau musibah yang bisa mengancam desa. Musibah yang telah terjadi pada beberapa tahun diantaranya adalah gagal panen, kematian tidak wajar, serta musibah alam seperti tanah longsor.
Keberadaan wayang Krucil menjadi media hegemoni yang efektif bagi kepala desa, dengan tujuan untuk melanggengkan kekuasaannya, dimana wayang Krucil pada tahun 2014 disahkan sebagai peraturan desa, dimana penyelenggaraan wayang Krucil wajib diselenggarakan, melalui karakteristik kepemimpinan yang kharismatik mistik, kharismatik filosofis, dan eufemistik, cerita sastra yang dipercaya dan diyakini oleh masyarakat secara sadar ataupun tidak, sehingga membuat masyarakat tunduk pada kultur sosial yang direduksi melalui hegemoni pertunjukan wayang Krucil, sehingga masyarakat bisa diarahkan pada keinginan kepala desa.

\section{Daftar Pustaka}

Arumsari, Nugraheni et al. Komunikasi Politik Kepala Desa dalam Mendorong Inovasi Pembangunan Desa: Studi Kasus Tiga Desa di Lereng Gunung Ungaran, Jawa Tengah. Politik Indonesia: Indonesian Political Science Review, [S.1.], v. 2, n. 1, p. 86-99, jan. 2017. ISSN 2503-4456. Available at: <https://journal.unnes.ac.id/nju/index.php/jp i/article/view/8488/5646>. Date accessed: 08 apr. 2018. doi:https://doi.org/10.15294/jpi.v2i1.8488.

Bachr, B. S. (2010). Meyakinkan Validitas Data Melalui Triangulasi Pada Penelitian Kualitatif. Jurnal Teknologi Pendidikan, 46 -62 .

Boer, K. M. (2012). Nude Photography, Eksploitasi Tubuh Pengatasnamaan Seni. Komunikator, Vol 04. N0. $01.46 \quad-\quad 58$. http://journal.umy.ac.id/index.php/jkm/articl e/view/190.

Chalik, A. (2015). Sintesis Mistik dalam Kepemimpinan Politik Jawa. Jurnal Review Politik, 5(2), 254-278. Retrieved from http://jurnalpolitik.uinsby.ac.id/index.php/jr p/article/view/69.

H.B. Sutopo. (2006). Penelitian Kualitatif: Dasar Teori dan Terapannya dalam Penelitian. Surakarta: Sebelas Maret University Press. 
Minarto, S. W. (2007). Jaran Kepang dalam Tinjauan Interaksi Sosial pada Upacara Ritual Bersih Desa. Bahasa dan Seni , 76 - 87.

Mudhoffir, A. (2014). Teori Kekuasaan Michel Foucault: Tantangan bagi Sosiologi Politik. MASYARAKAT: Jurnal Sosiologi, 18(1). Retrieved April 8, 2018, from http://www.ijil.ui.ac.id/index.php/mjs/article /view/3734/2973.

Nurgiyantoro, B. (2011). Wayang dan Pengembangan Karakter Bangsa. Jurnal Pendidikan Karakter, 18 - 34. https://journal.uny.ac.id/index.php/jpka/artic le/view/1314.

Nurrochsyam, M. W. (2013). Kresna Duta: AkarAkar Kekerasan dalam Pertunjukan Wayang. Jurnal Pendidikan dan Kebudayaan, 397 406.

http://jurnaldikbud.kemdikbud.go.id/index.p hp/jpnk/article/view/299

Prajayanti, D. U. (2012, April 12). Berkaca Pada Filosofi Tepa Selira "Sang Juragan Kayu" : Sebuah Konstruksi Sosial Kepemimpinan Jawa Joko Widodo. Skripsi , Pp. 1 - 116.

Rahman, d. N. (2012, september 17). Peran Kepemimpinan Jawa (Studi Eksplorasi pada CV Batik Indah Rara Djonggrang, y ogyakarta). Skripsi, pp. 1 - 65.

Christianto, W. (2012). Peran Dan Fungsi Tokoh Semar-Bagong Dalam Pergelaran Lakon Wayang Kulit Gaya Jawa Timuran. Jurnal Humaniora, 15(3), 285301./*doi:http://dx.doi.org/10.22146/jh.v15i $3.796 * 1$ doi:https://doi.org/10.22146/jh.v15i3.796

Sartini, N. W. (2009). Menggali Nilai Kearifan Lokal Budaya Jawa Lewat Ungkapan (Bebasan, Saloka, Dan Paribasa). Logat, 28 - 37. http://repository.usu.ac.id/bitstream/handle/ 123456789/17541/log-apr2009-

5\%20(4).pdf;jsessionid=5ECBB281CD421 D2F9CDC45C46C413997? sequence $=1$

Sulaiman, Z. (2017). Hegemoni Sastra dalam Kehidupan Sosial Budaya Masyarakat. Jurnal Ilmiah Program Studi Pendidikan Bahasa dan Sastra Indonesia, 27 - 33.
Sulaksono, D. (1). Filosofi Pertunjukan Wayang Purwa. IBDA: Jurnal Kajian Islam Dan Budaya, 11(2), 238-246. https://doi.org/https://doi.org/10.24090/ibda. v11i2.82

Sunarni, N. (2018). Drama Sebuah Alternatif Objek Penelitian Bahasa. Sastra Jepang, 61 - 69.

Suwardi. (2012). Sastra dan Budaya Jawa. Yogyakarta: Universitas Negeri Yogyakarta.

Bedjo Tanudjaja, B. (2005). Punakawan sebagai Media Komunikasi Visual. Nirmana, 6(1). doi:https://doi.org/10.9744/nirmana.6.1.

Tjintariani, Y. W. (2014). Tinjauan Visual Tokoh Wayang Tengul Di Bojonegoro. Jurnal Pendidikan Seni Rupa , 87 - 95.

Yudiarti, S. I. (2010). Wayang Mbeling Kreatifitas Dalang Sebagai Komunikator Sosial. Gelar Jurnal Seni Budaya, Vol 08 No. 01, 122 133, https://jurnal.isiska.ac.id/index.php/gelar/article/view/1317 